\title{
ESTUDIOS
}

\section{Alejo Carpentier: autor y obra en su época}

$\mathrm{U}^{\mathrm{N}}$ NA de las pupilas más sensibles y penetrantes de la generación vanguardista tal como la define José Juan Arrom en su lúcido y sugestivo estudio 'Esquema generacional de las letras hispanoamericanas, es la del novelista, musicólogo y poeta Alejo Carpentier.l Cubano por nacimiento, esencialmente europeo por educación y profundamente hispanoamericano por inclinación, ifigura entre los escritores más cultivados de lengua española en nuestro tiempo. No obstante, debido a su convicción de que "la vida no importa, es lla obra lo que cuenta", su posición en las letras de la Amética Hispana resulta un tanto indefinida. Así, aunque sus novelas hayan obtenido un gran éxito tanto en español como en los idiomas a los que se han traducido, cosechando numerosos premios y la aprobación de la crítica, su vida, su personalidad y su trayectoria artística no han encontrado la merecida resonancia. ${ }^{2}$ Intentemos por ello, situar autor y obra en su época, puesto que la literatura brota

I Bogotá, Instituto Caro y Cuervo, 1963, pp. 194-213. Nace Carpentier en 1904. Pertenece, por tanto, a la generación de 1924-1954.

2 Los dos mejores apuntes biográficos a los cuales casi siempre seguimos son los siguientes: "Alejo Carpentier, novelista antillano y universal" de Salvador Bueno, en La letra como testigo, Santa Clara, Cuba, Universidad Central de las Villas, 1957, pp. 153-179, y "Confesiones sencillas de un escritor barroco" de Alejo Carpentier, recogido por César Leante en Cuba, Año III, no. 24, abril 1964, pp. 30-33. El mismo artículo salvo dos o tres frases censuradas también aparece bajo el título de "Autobiogtafía de urgencia" en Insula, Madrid, Año XX, no. 218, enero 1965, pp. 3 y 13. 
como fruto de un hombre interpretando una realidad en un determinado momento, en una determinada circunstancia.

Sobre la base de los apuntes de Salvador Bueno en "Alejo Carpentier, novelista antillano y universal" y de César Leante en "Confesiones sencillas de un escritor barroco", tomamos conocimiento de los siguientes datos. Carpentier pasa su primera infancia en una finca de Loma de Tierra, del reparto $\mathrm{El}$ Cotorro, cerca de su ciudad natal La Habana, donde vio la luz el 26 de diciembre de $\mathrm{I}_{90}$ en la calle Maloja. Viaja en su niñez por Francia, Austria, Bélgica y Rusia. Crece en el seno de una familia de émigrantes que vino a Cuba en 1902 , dos años después de la independencia, aprende francés desde niño en el hogar, y español en el cálido ambiente tropical que le circunda. La familia paterna era oriunda de la Bretaña y el bisabuelo Alfredo Clerec-Carpentier uno de los primeros exploradores de las Guayanas en $1840 .^{3} \mathrm{El}$ padre, arquitecto francés, autor de numerosos edificios habaneros tales como la planta eléctrica de Tallapiedra, el Trust Company, y el viejo Country Club, se interesaba enormemente por el mundo español." Como nos cuenta Carpentier en sus recuerdos juveniles, su padre, que hablaba perfectamente el castellano, era violoncellista de afición, discípulo de Pablo Casals, y tenía una extensa biblioteca en que alternaban obras de Pío Baroja, Blasco Ibáñez, Pérez Galdós, con las de Anatole France, Víctor Hugo, y Emile Zola. La madre, rusa, que cursó estudios de medicina en Suiza, era profesora de idiomas y muy inclinada "hacia las letras". La afición de Carpentier por la música y la arquitectura, así como su conocimiento de la literatura francesa y española, en especial las novelas de Pío Baroja, gusto en parte heredado, han de ser factores decisivos en su obra de madurez. Las primeras lecturas que despiertan su sensibilidad literaria son de Emilio Salgari, Julio Verne y Alejandro Dumas. No nos extraña, por tanto, cuando nos cuenta que a los I 2 años comienza a escribir novelas y cuentos influidos por Salgari y France.

Después de su educación primaria en Cuba hace parte de los estudios secundarios en el Liceo Jason de Sailly de París. O como nos informa su coetáneo Juan Marinello, "... partió hacia París en la primera juventud, pero acusada ya, en armoniosa precocidad, su personalidad artística". 5 Y como bien observa Salvador Bueno, Carpentier se ve desarraigado en su mocedad, añadiendo una educación francesa a un fondo cubano, suma de diversas culturas:

3 S. Bueno, op. cit., p. 156.

4 A. Carpentier, "Confesiones sencillas", op. cit., p. 31.

5 "Una novela cubana", en Literatura bispanoamericand, Hombres-Meditaciones, México, Ediciones Universidad Nacional de México, 1937, p. 171. 
... lo europeo occidental, lo hispánico y lo africano en la mezcla rica de sus circunstancias ambientales. En la casa hogareña los diálogos y los libros traerán ecos de aquellas viejas culturas europeas, lo bretón y lo eslavo en conjunción fructífera. Afuera en la calle, en la ciudad, entre los amigos que surgen, entre la gente que pasa y conversa, va alimentándose con lo colonial español y con el trasplante africano que, a fin de cuentas, forman la esencial cubanía. Y el futuro narrador todo lo incorpora, de todo hace alimento para su espíritu. ${ }^{6}$

Cursa teoría musical en París y llega a ser en sus propias palabras "un pianista aceptable", aunque confiesa que su "... formación musical es riás bien autodidacta: asistencia a ensayos, convivencia con músicos..." y considera que "... todo escritor debe tener conocimiento de un arte paralelo, pues eso enriquece su mundo espiritual".7 A principios de la década de, los años 20 regresa a Cuba e inicia los estudios en la Universidad de La Habana con el fin de obtener el título de arquitecto. Empieza a hacer periodismo en I92т. Publica sus primeros trabajos literarios, como columnista, resúmenes de obras conocidas, en una sección titulada "Obras famosas" del diario habanero La Discusión. ${ }^{3}$ El mismo año abandona definitivamente la cartera universitaria "por motivos netamente personales" y parte otra vez para Francia. ${ }^{9}$ A su regreso se dedica completamente al periodismo y redacta artículos de crítica musical y teatral en La Discusión y El Heraldo de Cuba en r923 y r924. A fin de mejorar su situación económica acepta los más diversos trabajos periodísticos: actúa como jefe de redacción de una revista comercial, Hispania; escribe una historia de los zapatos para el órgano oficial de la Unión de Fabricantes de Calzados, y firma con seudónimo de "Jacqueline" la sección de modas de la revista Sacial. io an I924 ocupa el puesto de jefe de redacción de la revista Carteles. $Y$ en 1926 , invitado por el gobierno mexicano a tomar parte en un congreso de periodistas, viaja a México, donde conoce a Carlos Pellicer, a Jaime Torres Bodet, a José Clemente Orozco y traba estrecha amistad con Diego Rivera. ${ }^{11}$ Estos son años formativos en que se van definiendo paulatinamente los contornos de su personalidad artística. Llega a conocer a fondo los pintorescos barrios de su ciudad natal, descubriendo el singular

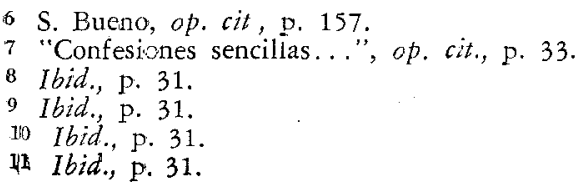


hechizo de la arquitectura colonial y el ambiente de La Habana Vieja. Impresiones imborrables éstas de las que nacen más tarde circunstancias y personajes de muchos de los cuentos, ensayos y novelas que se sitúan en parte, o tienen por asunto la capital cubana: Viaje a la semilla, La ciuddd de las columnas, $\mathrm{El}$ acoso y $\mathrm{El}$ siglo de las luces. De mucha mayor trascendencia es el hecho de que hierve al calor de los movimientos intelectuales e inquietudes políticas de los jóvenes, identificándose espiritualmente, y sin reservas, con el grupo cubano de su generación.

En el bosquejo biográfico a La pupila insomne de Rubén Martínez Villena, Raúl Roa describe cómo comienza a reunirse en La Habana de 1920 una tertulia de poetas, críticos e intelectuales jóvenes en el café "Martí" a la que acuden entre contertulios de momento, "transeúntes ilustres" y "algunos escritores extranjeros", Andrés Núñez Olano, Enrique Serpa, Guillermo Martínez Márquez, Alberto Lamar Scheweyer, Miguel Angel Limia, Arturo Alfonso Roselló, Regino Pedroso, Rafael Esténger, Ramón Rubiera, Juan Marinello y Rubén Martínez Villena.12 Esta tertulia tiene aproximadamente un año de vida. Después de una breve pausa reaparece en el café "El Fígaro" con casi el mismo grupo, al que ahora también se han agregado Jorge Mañach, "recién llegado de Harvard", Félix Lizaso y José Z. Tallet. ${ }^{13}$ En estos años, antes o después de su regreso a Francia, Alejo Carpentier debe frecuentar la peña literaria puesto que en I923 se asocia al grupo señalado por Roa: '... - los que antes se reunían en 'Martí', luego en 'El Fígaro' y compondrán posteriormente el 'Grupo Minorista' al calor de Social y del bufete de Emilio Roig de Leuchsenring-..."14 Aunque el "Grupo Minorista" compuesto por Carpentier, Martínez Villena, Roig de Leuchsenring, Luis Gómez Wangüiemert, Tallet y otros pretende ser un movimiento intelectual, sus miembros también protestan y participan vivamente en la oposición a la inmoralidad y los desmanes políticos del presidente Alfredo Zayas. Encabezados por el poeta y revolucionario Martínez Villena, Wangïemert, Schweyer, Lizaso, Ichaso, Mañach, Marinello, Tallet y otros cinco, se oponen en la llamada "Protesta de los Trece", en la Academia de Ciencias, a la venta del convento de Santa Clara a un precio irrisorio, uno de los inumerables turbios negocios de la época de Zayas. Más tarde también forman parte de la "Falange de Acción Cubana" fundada por Martínez Villena, cuya función es criticar al gobierno, y apoyan el fracasado movimiento insurreccional de la "Asociación de Veterano y Patriotas".

\footnotetext{
12 La Habana, Ucar García, 1943, pp. 22 y 23.

13 La pupila insomne, op. cit., p. 24 .

14 Ibid., p. 24.
} 
Sin embargo, Carpentier pone de relieve en La música en Cuba, que el "Grupo Minorista" al que se une desde los primeros momentos, no es fundamentalmente un movimiento político:

Al calor de la abortada revolución de Veteranos y Patriotas (I923), ... pronunciamiento... sin cohesión, ni dirección, ni ideología concreta, algunos escritores y artistas jóvenes que se habían visto envueltos en el movimiento... adquirieron el hábito de reunirse con frecuencia, para conservar una camaradería nacida en días agitados. Así se formó el Grupo Minorista, sin manifiestos ni capillas, como una reunión de hombres que se interesaban por las mismas cosas. Sin que pretendiera crear un movimiento, el minorismo fue muy pronto un estado de espíritu. Gracias a él, se organizaron exposiciones, conciertos, ciclos de conferencias; se publicaron revistas; se establecieron contactos personales con intelectuales de Europa y de América, que representaban una nueva manera de pensar y de ver. Inútil es decir que en esa época se hicieron los "descubrimientos" de Picasso, de Joyce, de Stravinsky, de Los seis, del Esprit Nouveau, y de todos los ismos. Los libros impresos sin capitulares andaban de mano en mano. Fue el tiempo de la "vanguardia", de las metáforas traídas por los cabellos, de las revistas tituladas, obligatoriamente, Espiral, Proa, Vértice, Hélice, etc. Además toda la juventud del continente padecía, en aquellos años , de la misma fiebre. ${ }^{15}$

En Cuba el vanguardismo del que forma parte el "Grupo Minorista", movimiento sin tendencias definidas al principio, empieza por arrojar lastre. Los "minoristas" sienten tan profundo desprecio por los últimos resplandores del modernismo preciosista, como por todas las manifestaciones artísticas del siglo xIx. Los pintores descubren las inovaciones del arte europeo, el expresionismo, el cubismo, el dadaísmo. Y Carpentier en "Variaciones sobre un tema cubano" nos informa que en la música ocurría algo semejante: "La aversión por el teatro lírico en general, y por la ópera italiana en particular, el anti-wagnerismo,' un anti-romanticismo casi agresivo, la desconfianza hacia todo lo que oliera a siglo XIX, formaba parte de la estética de ese grupo". ${ }^{16}$ En literatura, esta generación rompe, decidida y certera, con ritmos e imágenes tradicionales. Aunque los escri-

15 México, Fondo de Cultura Econćmica, 1946, p. 235.

16 Américas, Washington, Unión Panamericana, vol. 2, no. 3, marzo de 1950, p. 21 . 
tores jóvenes sienten un fuerte deseo de plasmar lo cubano y aclaman como héroe generacional a José Martí, también advierten que el pulso vanguardista late vigorosamente en Madrid y en las capitales hispanoamericanas. Por ello se identifican de nuevo con ". . una España muy olvidada desde los días de la independencia". Explica Carpentier: "Inicióse, entonces, una especie de retorno hacia lo español, con una intensificación de la conciencia nacional, muy debilitada por veinticinco años de cosmopolitismo imitativo". ${ }^{17}$ Es decir, el caótico remolino inicial de conflictos y tendencias varias donde influía el futurismo, el ultraísmo, el maquinismo, se aclara en dos corrientes fundamentales, a saber, el neobarroco y el populismo. La nueva promoción cubana sabe que por razón del tricentenario de la muerte de Góngora, en I927, los vanguardistas españoles aclaman calurosamente a este poeta. ${ }^{18}$ Junto con ello se abre camino una nueva apreciación de los poetas clásicos, tales como Quevedo y Lope de Vega, que en su época también escribieron versos sencillos de raíz tradicional. La tumultuosa resurrección de lo barroco y de lo popular toman formas distintas en España y en Cuba. Según José Arrom "Lo que para el andaluz de Granada desemboca en gitanismo... en la cuenca del Caribe, sin gitanos que enaltecer y sin gauchos que memorar,... lleva al encuentro del negro". $19 \mathrm{Y}$ así también lo asegura Carpentier: "Se verificó un proceso de acercamiento a lo negro enfatizado por el hecho de que los escritores y artistas de la etapa cosmopolita habían cerrado los ojos, obstinadamente, ante la presencia del negro en la isla avergonzándose de ello... Ahora en reacción contra ese espíritu discriminatorio, se iba hacia lo negro con un entusiasmo casi excesivo, hallando en su ámbito ciertos valores que se preferían a otros, tal vez más líricos pero de mucho menos fuerz:" $2 n$ $\mathrm{Y}$ en La música en Cuba, añade: "Por lo mismo que con ello se disgustaba a los intelectuales de viejo cuño, se iba con unción a los juramentos ñá ñigos, haciéndose el elogio de la danza del diablito. Así nació la tendencia aftocubanista, que durante más de diez años alimentaría poemas, novelas, estudios folklóticos y sociológicos. Tendencia que, en muchos casos, sólo llegó a lo superficial y periférico, al negro bajo palmeras ebrias de sol, pero que constituía un paso necesario, para comprender mejor ciertos

17 Américas, op. cit., p. 21.

I's Véase el contenido de la Revista de Avarace. Un detallado análisis de la revista se encuentra en el artículo de Carlos Ripoll: "La Revista de Avance (19271930) vocero de vanguardismo y pórtico de revolución", en Revista Iberoamericana, vol. XXX, no. 58, julio-diciembre, 1964, pp. 261-282.

19 J. J. Artom, Esquema Gener'acional..., op. cit., pp. 198 y 199.

20 "Variaciones sobre un tema cubano", op. cit., pp. 21 y 22. 
factores poéticos, musicales, étnicos y sociales, que habian contribuido a dar una fisonomía propia a lo criollo".21

Estas afirmaciones de Carpentier nos permiten dejar asentado que lo esencial en los años I920-1928 es que el autor participa plenamente en el vanguardismo cubano, comparte los anhelos de sus coterráneos, y encuentra amigos y colaboradores entre las figuras principales del movimiento. En esta época irá a menudo con un grupo de conocidos a escuchar las actuaciones profesionales del compositor Amadeo Roldán, recién regresado de Europa, quien obligado a ganarse la vida, dirige un conjunto musical en el cine "Fausto", en cabarets y en otros lugares elegantes como el Hotel Inglaterra de La Habana. Allí escuchará fragmentos de música de Ravel, Debussy, Stravinsky y obras de maestros contemporáneos tocadas por la pequeña orquesta de Roldán. En I925 el joven escritor alaba la Obertura sobre temas cubanos cuyo final tiene un pasaje para batería sola compuesta por instrumentos afrocubanos, de ritmos específicamente criollos. El estreno en el Teatro Nacional corresponde al triunfo de ciertos principios de la nueva estética que empieza a imponerse. Poco después de esta fecha Carpentier colabe:s con Roldán en cuatro libretos de partituras para dos ballets de asunto cubano y dos poemas coreográficos sugeridos por el éxito europeo de La consagración de la primavera de Stravinsky y El sombrero de tres picos de Manuel de Falla. Por las noches, cuando Roldán sale del cine "Fausto" y se reúne con él en el café "Las Columnas", surge la idea de La rebambaramba ( 1928 ), "Ballet colonial en dos cuadros" sobre grabados románticos que evocan "el día de Reyes" en La Habana de 1830.22 Y El milagro de Anaquillé ( (929), autocoregoráfico en un solo cuadro que evoca escenas del campo cubano y tiene lugar en un ingenio de azúcar. ${ }^{23}$ También elaboran los dos poemas coreográficos, Mata-Cangrejo y Azúcdr.24 Y por último, a principios del año 1927 , Carpentier, junto con Jorge Mañach, Juan Marinello, Francisco Ichaso y Martí Casanovas, forman el grupo de "Los Cinco", que actúa vigorosamente en la fundación de la Revista de Avance que desde el $x_{5}$ de marzo de 1927 al I5 de septiembre de I930 ha de ser el "vocero de vanguardismo" y órgano de expresión del movimiento en Cuba. Carpentier informará a los lectores acerca de asuntos musicales. Debido a la funesta situación política de la dictadura de Machado, Tallet y Lizaso ocuparán más tarde los puestos

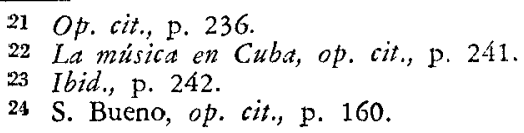


de Carpentier y Casanovas, arrestados por firmar un manifiesto contra el "asno con garras". A sicte meses de prisión en la cárcel de Prado, desde agosto de 1927 a marzo de I928, sucede el exilio político del escritor durante el cual el vanguardismo empezará a dar sus frutos.

Del Io al 9 de agosta de 1927 escribe la primera versión de su novela, ¡Ecue-Yamba-Ó!, historia aftocubana ( $\mathrm{i}$ Dios, loado seas! en dialecto ñáñigo), en la cárcel.25 Redactará la versión definitiva en París, eneroagosto de r933 y la editará el mismo año en Madrid. ${ }^{26}$ Por suerte, lo ponen en libertad condicional y un congreso de periodistas que tiene lugar en La Habana en marzo de $x 928$ le proporciona la oportunidad de huir del opresivo régimen machadista. Carpentier conoce al poeta surrealista francés Robert Desnos, en aquel entonces representante de un periódico argentino, quien le aconseja aprovechar la ocasión para salir de la isla. Desnos le ayuda a embarcar en el buque "España", prestándole el pasaporte y las identificaciones, y Mariano Brull, funcionario de la embajada de Cuba en Francia, le facilita el desembarque en Saint Nazaire. ${ }^{27}$ Al establecerse en París en I928, colabora con poemas y artículos sobre música en revistas parisienses y cubanas. Desde la capital francesa envia el poema Liturgia, publicado en el último número de la Revista de Avance, y Canción que aparece por primera vez en las hojas de la Revista de Oriente en r93I. En medio de los círculos musicales parisienses convive y colabora con los compositores franceses Darius Milhaud y Marius François Gaillard, el brasileño Heitor Villa-Lobos, y el cubano Alejandro García Caturla. Así nacen poemas, libretos y textos de las siguientes obras musicales: Yamba- $\sigma$, tragedia burlesca, música de M. F. Gaillard, estrenada en el Théâtre Beriza, París, I928; Poèmes des Antilles, neuf chants sur des textes de Alejo Carpentier, musique de M. F. Gaillard, Edition Martine, París, I929; Blue, Poema, música de M. F. Gaillard, Edition Martine; París; La Passion Noire, cantata para diez solistas, coro mixto y altoparlantes, música de M. F. Gaillard, estrenada en París, julio de 1932, y Dos poemas afrocubanos, Mari-Sabel y Juego Santo, para voz y piano, música de A. G. Caturla, Edition Maurice Senart, París, I929..28 También escribe una serie de artículos, Ensayos convergentes (1928) y dos novelas de asunto cubano, El castillo de Campana Salomón (Mitología de La Habana) y Semblante de cuatro moradas, que según el autor "... no vieron

25 ¿Ecue-Yamba-Ö!, Madrid, Eciitorial España, 1933, pp. 225 y 237.

26 Ibid., p. 25.

27 "Confesiones sencillas...", op. cit., p. 32.

28 Ecue-Yamba-Ó!, op. cit., p. 4, y Orbita de la poesía afrocubana 1928-37, Antología, selección, notas biográficas y vocabulario por Ramón Guirao, La Habana, Ucar García y Cía., 1938, p. 76. 
ni verán jamás la luzz de la imprenta, porque el escritor tiene que tener coraje de echar polvo sobre muchas páginas aunque mucho esfuerzo le haya costado llenarlas ..."'29

Desde su llegada a París en r928 Carpentier, presentado por Desnos, ingresa en el movimiento surrealista que junto con el vanguardismo ha de influir poderosamente en su obra. André Breton le invita a colaborar en la Revalution surrealiste donde conoce a Louis Aragon, Tristan Tzara, Paul Eluard, Georges Sadoul, Benjamin Peret, y a los pintores Giorgio de Chirico, Ives Tanguy y Pablo Picasso.30 Viene a escribir cuentos surrealistas como El estudiante, que entrega a corregir a Robert Desnos, cuyos ensayos a su vez traduce al español y publica junto con otras traducciones de Jean Giono debidas a la pluma de Félix Pita Rodríguez. Los artículos de Desnos, Giono y otros escritores franceses traducidos al español, aparecen en I93I en una pequeña revista, Imán, cuyo jefe de redacción es el mismo Carpentier, sufragada por la escritora argentina Elvira de Alvear. Aunque la revista tuvo "muy escasa circulación de la cual apenas se editó un solo número, en París" es curioso constatar que Carpentier, pot medio de Rafael Alberti, conoce la poesía de Pablo Neruda, quien le manda el manuscrito de Residencia en la tierra desde Java." Se le pagan los derechos de autor a Neruda. Pero como Imán cierra las puertas cuando Elvira de Alvear regresa inesperadamente a la Argentina, Carpentier envía Residencia en la tierra a Madrid donde José Bergamín lo publica en Cruz y Raya en I934.

En I933, después de acabar su primera novela ; $\vec{E} c u e-Y a m b a-\widehat{O} !$ en París, decide pasar una temporada en Madrid por motivo de la publicación del libro. Participa en la vida intelectual madrileña, y conoce a Federico García Lorca, Antonio Marichalar, Pittaluga. Acude a la peña literaria del Café Correos frecuentada por Lorca, quien le persuade a que haga otra visita a Madrid al año siguiente a fin de ver el estreno de Yerma.32 Al caer el régimen de Machado (1935) hace un viaje a Cuba en 1936, regresa a París y no vuelve a Madrid hasta después de estallar la Guerra Civil Española. A través de la "Maison de la culture" cuyo director es Louis Aragon, se convoca el II Congreso Internacional de Escritores Antifascistas en el Madrid de 1937 sitiado por las fuerzas de Franco. Carpentier forma parte de la delegación cubana compuesta de Juan Marinello, Nicolás Guillén, Félix Pita Rodríguez, Leonardo Sánchez Fernández. Hace el viaje París-Valencia-Madrid a fines de junio

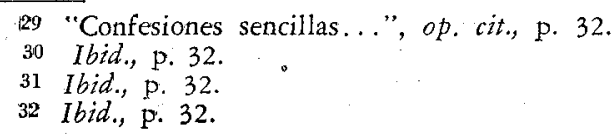


acompañado del poeta peruano César Vallejo, André Malraux y los mencionados Marinello y Pita Rodríguez. En este período también debe conocer al poeta americano Langston Hughes, cuya poesía graba en París.

En 1932 Carpentier empieza a trabajar en la radiodifusión francesa donde ejecuta tareas de efectos de sonidos y sincronización musical, actividades que ha de ejercer en Francia hasta I939. Viene a ser director de los Estudios Foniric donde dirige la producción de discos y programas de radio con las más avanzadas técnicas. Allí colabora con Robert Desnos, Antonin Artaud y Jean Louis Barrault en la elaboración de diversos programas entre los cuales figuran los siguientes: la grabación del poema de Walt Whitman, "Saludo al mundo, en la que se utilizó por primera vez una cinta magnética", la adaptación radiofónica por Desnos del cuento El asesinato de la calle de la Morgue de Edgar Allan Poe, y el "fresco radiofónico" de El libro de Colón de Paul Claudel, en la que actuó Jean Louis Barrault y cuyo estreno realizó Radio Luxemburg en $1939 .{ }^{33}$ También dirige la grabación de poesías de Langston Hughes, Paul Eluard, Louis Aragon, Rafael Alberti y otros, recitadas por los propios autores. Su interés en problemas de sincronización musical le lleva a escribir el libreto para una ópera ae iEdgar Varese, padre de la música electrónica, y a realizar el texto y el montaje de una película documental Le Vaudou. ${ }^{34}$ En este periodo le une estrecha amistad con Robert Desnos y frecuenta $l_{O S}$ círculos de Raymond Queneau, Michel Leiris, Ribemont Dessaignes, Roger Vitrac y Jacques Prevert. ${ }^{35}$

La residencia en París de I928 a I939 enriquece el mundo del escritor y le orienta hacia nuevas funciones expresivas. Se ahonda y refina su sensibilidad al mismo tiempo que se aleja de las manifestaciones demasiado provincianas del afrocubanismo y del surrealismo. Carpentier nos asegura que se apartó del movimiento surrealista cuando advirtió que no iba a contribuir con nada nuevo. $Y$ en sus memorias resume lo que esta etapa agregó a su formación intelectual: "Me enseñó a ver texturas, aspectos de la vida americana que no había advertido, envueltos como estábamos en la ola de nativismo traído por Güiraldes, Gallegos y José Eustasio Rivera. Comprendí que detrás de ese nativismo había algo más; lo que llamo los contextos: contexto telúrico y contexto épico político: el que

33 "Confesiones sencillas...", op. cit., p. 32, y "Notas sobre la narrativa de Alejo Carpentier" de Pedro Lastra, en Anales de la Universidad de Cbile, Año CXX, no. 125, primer trimestre de 1962, p. 95.

34. Ibid., p. 32 y p. 95.

35 Sobre las relaciones entre Carpentier y Desnos, véase el ensayo-elegía "Ser y estar", Robert Desnos, el hombre poeta; y dos ensayos de Desnos, ambos en Tientos y diferencias (ensayos), de Alejo Carpentier, México, Universidad Nacional Autónoma de México, 1964, pp. 101-107 y 137-149. 
halle la relación entre ambos escribirá la novela americana". ${ }^{36}$ Los largos años de destierro, el inicio de una cuajada madurez, despertaron su conciencia nacional imbuyendo en su alma la convicción y la necesidad de universalizar las experiencias del vanguardismo. El resultado fue la valorización de la realidad americana y la intuición de que su futuro como artista consistía en expresar y definir la esencia de América: "Sentí ardientemente el deseo de expresar el mundo americano. Aún no sabía cómo. Me alentaba lo difícil de la tarea por el desconocimiento de las esencias americanas. Me dediqué durante largos años a leer todo lo que podía sobre América, desde las Cartas de Cristóbal Colón, pasando por el Inca Garcilaso hasta los autores del siglo dieciocho. Por espacio de casi ocho años creo que no hice otra cosa que leer textos americanos. América se me presentaba como una enorme nebulosa, que yo trataba de entender porque tenía la oscura intuición de que mi obra se iba a desarrollar aquí, que iba a ser profundamente americana". ${ }^{37}$

Embargado con los mismos sentimientos que el protagonista de su novela Los pasos perdidos, Carpentier deja Europa con cierto desengaño al estallar la Segunda Guerra Mundial: "Ya me cansaba Paris y en I939, sin más razón que la nostalgia de Cuba, cerré mi apartamento y emprendí el regreso a La Habana". 38 Al volver a su país es nombrado director de la radiodifusora del Ministerio de Educación. Como codirector de la estación de radio C.M.Z., dirige, produce y escribe programas de radiodifusión. ${ }^{39}$ También enseña historia de la música en la Universidad de La Habana. A fines del año I943, acompañado de su mujer Lilia y de un amigo francés, Louis Jouvet, emprende un corto viaje a Haití, donde recorre las regiones costeras, el norte y la Meseta Central, visitando las ruinas de Sans-Souci y la Ciudadela de la Ferrière, la Ciudad del Cabo y el antiguo palacio de Paulina Bonaparte. Al regresar a Cuba empieza la redacción de $E l$ reino de este mundo, testigo del violento pasado de Haití y del alucinante reinado de Henri Cristophe. La novela no ve la luz hasta mayo de 1949 porque también inicia trabajos de otra índole. En 1944 publica el relato Viaje a la semilla en una edición limitada a roo ejemplares. En poco tiempo este cuento magistral forma parte de innumerables antologías del cuento hispanoamericano. Cuando Carpentier aparece en México, la editorial del Fondo de Cultura Económica le sugiere que escriba una historia de la música en Cuba. Después de detenida labor

36 Tientos y diferencias op, cit., p. 32 .

37 "Confesiones sencillas...", op. cit., p. 32.

38 Ibid., p. 32.

39 S. Bueno, op. cit., p. 162. 
documental en periódicos, gacetas, revistas coloniales y oscuros archivos de La Habana y de Santiago de Cuba que revelan inesperada fuente de hallazgos en manuscritos inéditos, publica el excelente estudio La música en Cuba, de gran importancia para la musicografía, en 1946. Allí presenta en forma sistemática y completa el desarrollo de las producciones musicales cultas y folklóricas cubanas.

En I945, convidado por un amigo, Carlos E. Frías, a organizar una estación de radio en Venezuela, se traslada a Caracas donde ha de permanecer más de catorce años. Desempeña la cátedra de historia de la cultura en la Escuela de Artes Plásticas desde I946 hasta I954. También ocupa un cargo en una empresa publicitaria, y por diez años escribe una columna para el diario caraqueño El Nacional que premia Los fugitivos como el mejor cuento publicado en el periódico el año de I946. Aprovecha su estancia en Venezuela para conocer más a fondo la naturaleza del continente americano y alentado por el deseo de completar esta visión, en I947 emprende un viaje al interior. Asegura el autor que ". . este país es como un compendio del Continente: allí están sus grandes ríos, sus llanos interminables, sus gigantescas montañas, la selva. La tierra venezolana fue para mí como una toma de contacto con el suelo de América y meterme en sus selvas, conocer el cuarto día de la Creación".40 Primero atraviesa zonas deshabitadas del país hasta llegar a Ciudad Bolívar, a orillas del Orinoco. En una navegación de veinte días en la cubierta de una lancha que lleva animales domésticos, y haciendo escala en las pequeñas poblaciones, llega a Puerto Ayacucho, a las regiones del Alto Orinoco, y a San Carlos del Río Negro cerca de las vías fluviales que unen el Orinoco al Amazonas y al Brasil. Allí convive con algunas de las más primitivas tribus americanas. Como nos cuenta el escritor: "Entonces surgió en mí la primera idea de Lios pasos perdidos. América es el único continente donde distintas edades coexisten, donde un hombre del siglo veinte puede darse la mano con otro del Cuaternario o con otro de poblados sin periódicos ni comunicaciones que se asemeja al de la Edad Media o existir contemporáneamente con otro de provincia más cerca del romanticismo de $185^{\circ}$ que de esta época. Remontar el Orinoco es como remontar el tiempo". ${ }^{41}$

En Caracas, en marzo de I948 Carpentier da los últimos toques a El reino de este mundo, publicado en México, en la primavera de I949. Por primera vez en más de Is años concluye una novela. Durante esta larga época de estudios, periodismo, crítica musical y publicación de cuen-

49 "Confesiones sencillas...", op. cit., p. 33.

41 Ibid., p. 33. 
tos en Francia, Cuba y Venezuela ha forjado y afilado sus armas literarias, y lo ha hecho con una asombrosa cultura. Cuenta 44 años cuando edita su segunda novela, fruto aventajado de este enriquecimiento interior. Comparado con ;Ecue-Yamba-OIl, donde todavía aparecen ciertos tanteos de principiante, $E l$ reino de este mundo ya es recia obra de madurez que deslumbra por el firme manejo de la materia narrativa y por la brillantez del estilo. Con este libro se inicia el período más fecundo de su carrera y en general, cada una de las obras posteriores marca una nueva etapa que supera o amplía en cierto aspecto a la anterior.

La idea que surge del viaje a la selva venezolana en 1947 se plasma en Los pasos perdidos, que sale en México en r953. La traducción francesa de El reino de este mundo, Le Royaume de ce Monde, es seleccionada por la "Société des Lecteurs de France" como el mejor libro del mes, en I954. Carpentier también toma parte vigorosa en la vida intelectua] venezolana: junto con Arturo Uslar Pietri y Miguel Otero Silva compone el jurado de I95I-I952 seleccionador de premiados por El Nacional, y participa en los festivales de música latinoamericana de Caracas. Sigue enviando artículos a revistas americanas, entre ellas la Revista de América de Bogotá, Américas de Washington y el Musical Quarterly de New York.

Fn 1956 publica la novela corta $E l$ acoso, sobre un sangriento episodio entre bandos de terroristas enemigos, durante la larga época de desórdenes que siguió a la caída del dictador Machado. También comienza a redactar $E l$ siglo de las luces, inspirado en parte en un viaje que realiza al Golfo de Santa Fe en la costa venezolana, cuya descripción encontramos en la jornada XXVI del tercer capítulo de esta obra. El mismo año viaja a Francia. La traducción de Los pasos perdidos lleva el título de Le Partage des Eaux, es decir "La separación de las aguas", porque la versión francesa del original, "Les Pas Perdus", corresponde al de una obra de André Breton (París, Nouvelle Revue Française, I924), y otra de Bernard Fallet.42 Carpentier pasa unos días en Guadalupe cuando el avión hace escala forzada en la isla. $Y$ allí, en un lugar llamado "le Gosier", conoce a un corso, dueño de un restaurante-museo, quien le habla de las fechorías de los piratas y filibusteros antillanos. Las hazañas de cierto aventurero Víctor Hugues, oriundo de Marsella, vencedor de las fuerzas inglesas en la isla, ejecutor del decreto para la abolición de la esclavitud y paladín de la Revolución Francesa en las Antillas le causan profunda impresión. Al investigar el asunto durante su estancia en París, advierte que, efectivamente, se trata de un personaje histórico olvidado desde hace mucho tiempo, y decide usarlo como uno de los protagonistas

42 S. Bueno, op. cit., p. 178. 
principales de El siglo de las luces, que no se publica hasta tres años después de su regreso a Cuba: "El triunfo de la Revolución Cubana me hizo pensar que había estado ausente de mi país demasiado tiempo... volví en mayo para estar un mes. Luego deshice mi casa en Venezuela y regresé definitivamente en julio del '59, para asistir al primer 26 de Julio. Traía en la maleta una nueva novela, El siglo de las luces, que había comenzado a escribir en Caracas en 1956 y terminado en la isla de Barbados dos años más tarde: pero necesitaba retoques y el cambio que se observaba en la vida y en la sociedad cubanas me resultó demasiado apasionante para que pudiera pensar en otra cosa. Por eso no se publicó hasta I962". 43 Entre 1956 y I959 termina, pues, El siglo de las luces, y vende los derechos cinematográficos de Los pasos perdidos a un consorcio internacional, que piensa distribuir la película a través de United Artists. El proyecto de filmación ha sido emprendido y abandonado por varios directores. Entre las últimas tentativas de adaptar una de sus novelas para el cine, que tampoco se llevó a cabo, cuenta la de Luis Buñuel sobre el guión del dialoguista francés Louis Sapin, en Cuba, poco después de la revolución castrista. Carpentier también lanza en 1958 Guerra del tiempo (tres relatos y una novela), compuesto de Viaje a la semilla y El acoso, publicados anteriormente, y dos cuentos inéditos, El Camino de Santiago y Semejante a la nocbe.

Desde 1959 Carpentier reside otra vez en La Habana, donde ejerce el cargo de director ejecutivo de la Editorial Nacional de Cuba, fundada en mayo de 1962. Según el autor en "La actualidad cultural de Cuba", este órgano de gobierno revolucionario "...centraliza, coordina, organiza, planifica ... las necesidades editoriales de los siguientes organismos: Ministerio de Educación... Consejo de Universidades (La Habana, Las Villas y Oriente); las ediciones de la Academia de Ciencias, Editorial Juvenil (libros cuidadosamente ilustrados... que incluyen $L a$ cabaña del Tío Tom, La edad de oro de José Martí, así como el Tom Sawyer de Mark Twain); las ediciones tecnológicas, y por el conducto del Consejo Nacional de Cultura, los requerimientos de numerosas instituciones". ${ }^{14}$ Entre ellas también figuran la UNEA (Unión de Escritores y Artistas de Cuba) que se encarga de ediciones de autores modernos, de la que el mismo Carpentier es vicepresidente. El Archivo Nacional (documentos históricos), la Biblioteca Nacional (textos de iconografías históricas), la UNES$\mathrm{CO}$ (Organización de las Naciones Unidas para la Educación, la Ciencia

43 "Confesiones sencillas...", op. cit., p. 33.

44 A. Carpentier, "La actualidad cultural de Cuba" en Sur, Buenos Aires, 293, marzo y abril de 1965 , p. 64. 
y la Cultura), el ICAIC (Instituto de Artes Cinematogtáficas Cubanas), y la Casa de las Américas que orgainza concursos anuales de poesía, cuentos, ensayos, novelas y teatro, tanto como la impresión de clásicos americanos: el Popol Vuh, Machado de Assis, César Vallejo y otros. ${ }^{45}$ Desde I959 hace a menudo la crítica literaria en la Gaceta de Cuba, órgano de la UNEA, y colabora en el gráfico mensual habanero Cuba, y en publicaciones extranjeras tales como Sur, Insula y Les Langues Modernes. A partir de 1964 también dirige un programa cultural de Radio Habana en onda corta, "La cultura en Cuba y en el mundo", donde charla media hora por semana sobre sus temas predilectos: la novela y la música en la América Latina, la novelística de Carlos Fuentes, el compositor Heitor Villa-Lobos, y su propia obra. A fines de I964 publica en México Tientos $y$ diferencias, una colección de ensayos sobre diversos temas: Problemática de la actual novela latinoamericana; Del folklorismo musical; La ciuddd de las columnas; Ser y estar; De lo real y maravillosamente americano. En la primavera de 1965 realiza una gira de conferencias por distintas universidades francesas. Actualmente acaba de terminar un nuevo libro, que ha de ver la luz de la imprenta próximamente: $E l$ año 59, que se desarrolla en La Habana, "primera parte de una trilogia inspirada en la Revolución Cubana". El capítulo primero ya apareció en la revista Casa de las Américas, octubre-noviembre de I964. También está escribiendo una obra teatral en torno a Hernán Cortés y Doña Marina, tragedia titulada El aprendiz brujo. 46

Creemos que en lo expuesto hemos representado, con la contracción de medida que reclama la perspectiva, un bosquejo fiel de la vida, influencias ambientales y trayectoria artística de Alejo Carpentier. Conviene ahora a nuestro propósito de situar autor y obra en su época volver la vista por un momento a la producción literaria, y esbozar el contorno de sus libros principales. No nos detendremos, por tanto, a analizar su poesía o sus artículos de orden periodístico o de crítica musical con los que contribuyó a periódicos y revistas tales como Chic, Musicalia, Social, Carteles, Suplemento del Diario de la Marina, Revista de Avance, Revista de la Habana, Nueva Revista Cubana, El Nacional, Sur, Américas, Musical Quarterly, etc., para citar apenas las más importantes.

Como ya indicamos anteriormente, Carpentier se identificó con la promoción cubana de la generación vanguardista, siendo uno de los primeros en producir obras dentro de la corriente afrocubana, a la que más

45 A. Carpentier, "La actualidad cultural de Cuba", op. cit., p. 64.

46 Claude Fell, "Recontre avec Alejo Carpentier", Les Langues Modernes, Par:s, 59e Année, no. 3, Mai-Juin 1965, p. 108. 
tarde también contribuyeron con colecciones de cuentos, ensayos y leyendas africanas Rómulo Lachatañeré en iiOh mio Y'emanyá!! (I938), Lydía Cabrera en Cuentos negros de Cuba (I940), y Ramón Guirao con su recopilación de Cuentos y leyendas negras de Cuba (I94?). Según lo indica el título de "Eccue-Yamba-O!', historia afrocubana, la obra se sitúa dentro de esta corriente literaria. Afirma Fernando Alegría en "Alejo Carpentier: realismo mágico" que es "... novela semidocumental sobre el mundo mágico primitivo de un sector de la población negra en Cuba. Parte importante juegan en ella los ritos religiosos, las ceremonias de iniciación, las fórmulas de encantamiento, el substrato ñáñigo de gentes que viven en una etapa de representación colectiva, prelógica y mistica, en el medio mismo de una civilización moderna" ${ }^{47} \mathrm{Y}$ en particular trata de la infancia, adolescencia y mocedad del negro Menegildo Cué, criado en el campo y muerto por un bando rival de negros en un arrabal de la ciudad de La Habana en la época que sigue a la Primera Guerra Mundial. Allí aparecen cuadros de la vida rural: el tiempo de la zafra en la región azucarera alrededor del ingenio Central San Lucio, la explotación económica de la tierta y de los campesinos por el consorcio extranjero, el huracán que azota el batey de la familia Cué. Menegildo crece al' son de ritmos y cadencias de atabales en días de fiesta, y participa en las brujerías y supersticiones de los santeros.

De noche, regresando de una celebración de año nuevo en el caserío, se enamora de la negra Longina, amancebada con un haitiano. Acaba peleando con su rival y lo deja medio muerto a la vera del camino. La puñalada le vale deportación a la ciudad y meses de presidio en la cárcel de La Habana. Al salir de la prisión se junta con su amante, en un cuartucho alquilado en un barrio pobre, e ingresa en una de las asociaciones secretas de negros. Toma parte en complejos rituales del rompimiento ñáñigo, participando en danzas y cantos de ceremonias iniciacas. En un centro espiritista de un suburbio habanero, donde los socios del conjunto musical "Sexteto de Física Popular" se han reunido a tocar y a cantar durante la Nochebuena, el grupo es asaltado y acuchillado por miembros del conjunto enemigo, "Alma' Tropical". Menegildo se desangra y muere "... con la yugular cortada por una cuchillada". Longina consigue escapar y volver al campo donde "... se aprieta en su propia entraña y, con irresistible energía, suelta una semilla nueva y victoriosa", dando a luz al hijo de Menegildo en el bohío de los Cué.4B

47 Humanitas, Anuario del Centro de Estudios Humanísticos, Universidad de Nuevo León, México, I, no, 1, 1960, p. 349.

48 Ibid., p. 351. 
Dada la época en que se escribió la obra, el autor aporta una nueva visión de la realidad cubana, tanto en el tema como en el logrado esfuerzo de incorporar a la novela la rica veta inexplorada del folklore cubano, elevándose a un plano artístico. Consigue este propósito prestando minuciosa atención a los detalles de las tradiciones y costumbres que describe, y el repertorio de términos afrocubanos que recoge en un glosario. Los personajes se expresan en forma dialectal, usan frases de raíz popular, aluden a héroes de la mitología criolla - la mulata María de la O, Manita en el Suelo, Candita la Loca-y entonan sones y canciones como la del "chévere congo Papá Montero", tan celebrado en la poesía por Nicolás Guillén, Alfonso Reyes y Carpentier: 'Señores / Señores / Los familiares del difunto me han confiado / Para que despida el duelo / Del que en vida fue / Papá Montero / ¡A llorar a Papá Montero! / ¡Zumba! / Canalla rumbero! /." A' esto se añade el carácter documental ya señalado por Salvador Bueno, que la obra adquiere por medio de fotografías de atabales, maracas, objetos rituales, y las divinidades sincréticas, Virgen de la Regla-Yemanyá, San Lázaro-Babayú-Ayé, Santa Bárbara-Shangó de Guinea, Dios del trueno. También se incluyen reproducciones de oraciones y símbolos de las potencias ñáñigas. No obstante Carpentier expresa todos estos elementos populares en un estilo elegante, pulido $y$, según el autor, lleno de "...metáforas, de símiles mecánicos, de imágenes de un aborrecible mal gusto futurista...", que llevó a Juan Marinello a calificarlo de "... tan artista como hombre de letras, tan ansioso de primitivismos como esclavo de refinamientos".49 Tal vez la valorización más justa de ¡Écue-Yamba-Ö! sea la del propio escritor, que en dos ocasiones distintas, "Rencontre avec Alejo Carpentier" recogido por Claudie Fell y Problemaitica de la actual novela latinoamericana, hizo los siguientes comentarios sobre su obra:

Au début du $\mathrm{XX}^{\mathrm{e}}$ siècle, l'influence du naturalisme français de Zola a été capitale. Zola jouissait d'une véritable audience en Amérique latine. Il se rendait par exemple jusqu'à une mine ou à un lieu de travail déterminé puis il écrivait un roman à propos de ce qu'il venait de voir. Mais il faut se détacher de cette 'observation'. Ainsi, dans mon premier roman: ¿Ecue-Yamba-Ö!.. j'ai suivi un chemin absolument parallèle. . .50

49 "Confesiones sencillas...", op. cit., p. 33, y "Una novela cubana", en Literaturct bispanoamericana, op. cit., p. 171.

50 Les Langues Modernes', op. cit., p. 104. 
En una época caracterizada por un gran interés hacia el folklore afrocubano recién "descubierto" por los intelectuales de mi generación, escribí una novela... cuyos personajes eran negros de la clase rural de entonces. Debo advertir que crecí en el campo de Cuba en contacto con campesinos negros e hijos de campesinos negros, que, más tarde, muy interesado por las prácticas de la santería y del "ñan." guismo" asistía a inumerables ceremonias rituales. Con esa "documentación" escribí una novela que fue publicada... en pleno auge del "nativismo" europeo. Pues bien: al cabo de veinte años de investigaciones acerca de las realidades sincréticas de Cuba, me di cuenta de que todo lo hondo, lo verdadero, lo universal, del mundo que había pretendido pintar en mi novela había permanecido fuera del alcance de mi observación. Por ejemplo: el animismo del negro campesino de entonces; las relaciones del negro con el bosque; ciertas prácticas iniciacas que me habían sido disimuladas por los oficiantes con una desconcertante habilidad. Desde entonces desconfío, de modo cada vez más fundado, de toda una literatura que solian presentarnos, hasta hace poco, como la más auténtica de América. ${ }^{51}$

Une vision locale et ruraliste d'un pays ne signifie rien. ${ }^{52}$

En los once años que transcurren entre la publicación de ;Ecue-Yamba-Ö! (I933), y la siguiente obra de ficción Viaje a la semilla (r944), hay un asombroso cambio de perspectiva. Aunque en la novela afrocubana abunden alusiones al mundo mágico de la liturgia ñáñiga, en ;ÉcueYamba- $\sigma$ ! predomina el anhelo realista y documental de presentar una actitud renovadora frente al sector negro de Cuba, despreciado y casi desconocido hasta entonces. Es decir, a pesar del tema novedoso y de determinadas innovaciones estilísticas, el autor seguia un camino paralelo al de la tradicional novela hispanoamericana. En cambio, en Viaje a la semilla, si bien continúa el enfoque realista, ahora lo encontramos aplicado a una situación absolutamente inverosímil y artificiosa frente a las apariencias del mundo real. Pero una vez que aceptamos el presupuesto de esta condición absurda, el relato resulta de tremenda verosimilitud $y$ de contundente fuerza.

El fantástico punto de partida es nada menos que la reversibilidad tel tiempo, personificado por la figura de un viejo al comienzo de la narración. Presenciamos la demolición de una casa señorial por obreros que desmontan el tejado y derriban muros en el sol del atardecer. Al caer la

51 Tientos $v$ diferencias, op. cit, pp. 12 y 13.

52 Les Langues Modernes, op. cit., p. 104. 
noche, en la escena siguiente, se inician extraños acontecimientos: se cierran los boquetes en las murallas, el tejado se vuelve a cubrir de tejas, se abren las ventanas, los corredores se pueblan de gente y contemplamos el cuerpo de don Marcial, Marqués de Capellanías, en capilla ardiente. Cuando en la próxima escena el difunto se levanta de su lecho de muerte, una serie de paradójicas imágenes, "los cirios crecieron lentamente, perdiendo sudores... Cuando el médico movió la cabeza con desconsuelo profesional, el enfermo se sintió mejor", nos dan la desconcertante sensación de que nos encontramos en el mundo de la colonia a principios del siglo xrx, donde parece el tiempo retroceder inexorablemente hacia el pasado. A partir de este momento nos acercamos al desenlace del relato como en una película cinematográfica que corre al revés, desde el final al principio. A medida que se cobra el hilo del tiempo cambia el punto de vista psicológico del marqués, el cual se "desvive" de viejo a mozo y a niño. Las imágenes se deslizan ante los ojos del lector con creciente velocidad para hacerse luego completamente borrosas al reintegrarse la criatura a las entrañas de la madre, y perderse por último en el semen derramado en la oscuridad uterina.

Viaje a la semilla refleja la nueva tendencia de la novelística contemporánea hispanoamericana, el realismo mágico, señalado y definido por Angel Flores: "Finding in photographic realism a blind alley, all the arts - particularly painting and literature - reacted against it and notable writers of the First World War period came to re-discover symbolism and magical realism ... The novelty ... consisted in the amalgamation of realism and fantasy. Each of these, separately and by devious ways, made its appearance in Latin America: realism, since the Colonial Period but especially during the I $880^{\circ}$ 's; the magical, writ large from the earliest -in the letters of Columbus, in the chroniclers, in the sagas of Cabeza de Vaca- entered the literary mainstream during Modernism". 53 Y es justamente en maravillosos relatos de conquistadores de América y deslumbrantes episodios del pasado americano donde Carpentier encuentra tema para muchos de sus cuentos, ensayos y novelas: Viaje a la semilla, Los fugitivos, La música en Cuba, El Camino de Santiago, Semejante a la noche, El reino de este mundo y $E l$ siglo de las luces. Dice el autor, "Me apasiono por los temas históricos por dos razones: porque para mí no existe la modernidad en el sentido que se le otorga; el hombre es a veces el mismo en diferentes edades, y situarlo en su pasado puede ser también situarlo en su presente. La segunda razón es que la novela

53 Angel Flores, "Magical realism in Spanish American Fiction", Hispania, rol, XXXVIII, no. 2, May 1955, pp. 188 y 189. 
de amor entre dos o más personajes no me ha interesado jamás. Amo los grandes temas, los grandes movimientos colectivos. Ellos dan la más alta riqueza a los personajes y a la trama" ${ }^{54}$ Esta preocupación por la historia le lleva a investigar el pasado musical americano en La música en Cuba donde sigue, en líneas generales, su desarrollo durante los siglos XVI y XVII, analizando distintas corrientes que confluyeron en la colonia. El escritor examina el estrato indígena, el aporte español del romancero y el influjo de la tradición oral negta desde los primeros tiempos. Sondea el origen de muchos instrumentos arribados a la isla de los cuatro vientos, sacabuches, vihuelas, atabales, maracas y el güiro, y comenta de paso, la famosísima canción popular del siglo xvi, el Son de la Ma Teodora. En el capítulo segundo, menciona un músico habanero de la misma época, en torno del cual estructura un cuento, en Guerra del tiempo, El Camino de Santiago: "... en I557 La Habana no contaba con más músico que un flamenco, Juan de Emberas (sic), que tocaba el tambor cuando había un navío a la vista...".55 También alude a los origenes del tango y de la habanera, y a bailes populares, tales como la guaracha y el chuchumbé, que en su tiempo hicieron las delicias de los aficionados. Sus observaciones brillan por la luz que arroja sobre el admirable maestro Esteban Salas (?-I803), autor de numerosas misas, villancicos y letanías que yacian olvidadas en polvorientas gavetas de la catedral de Santiago desde principios del siglo xrx. Salas es otro personaje histórico que aparece más tarde en las páginas de una obra de ficción, El reino de este mundo.56 En el capítulo sexto, al hablar de la introducción de la contradanza en Cuba, describe además la colonización en Santo Domingo; los levantamientos de esclavos en la isla que iniciaron la independencia haitiana, y la vida de los exilados que huyeron a Cuba. Estos comentarios a la historia de Haití aclaran también muchos episodios de El reino de este mundo. La acción de gran parte de la novela, por ejemplo, se basa en la detallada información resumida en La música en Cuba. Los capítulos posteriores recogen lucidos tetratos de figuras tales como las de Manuel Saumell, autor de contradanzas, e Ignacio Cervantes, el mayor compositor cubano del siglo XIx. Entre las páginas más interesantes para nuestro estudio figuran las secciones dedicadas al afrocubanismo, a Amadeo Roldán (1900-r939) y a Alejandro García Caturla (Igo6-

54 "Confesiones sencillas...", op. cit., p. 33.

55 La música en Cuba, op. cit., p. 44.

56 Compárense las siguientes páginas del estudio musicográfico con las de la novela. Esteban Salas, 62, 63,-97, 98. Santo Domingo, 89-94: 96-75, 84; 99-91; 100-77, 83, 84, 85, 86; 101-93, 94, 96, 97. Las ediciones son La música en Cuba, op. cit., y El reino de este mundo, México, Edición y Distribución. Ibero Americana de Publicaciones, S. A. 
x940). En la primera el autor explora fuentes musicales africanas, y su proceso de transculturación que condujo al mestizaje de elementos españoles y africanos, característico de Cuba y de muchas otras regiones de la América Latina. Carpentier esboza la historia de cabildos negros, comparsas del Día de Reyes y carnavales, y asociaciones ñáñigas. También explica ciertos aspectos de los rituales y ceremonias religiosas de esta "masonería popular", tales como los toques profanos y los que "hacen bajar el santo", examinando el influjo que tuvieron en el arte y en la música. Como Roldán y Caturla son contemporáneos de Carpentier, son sumamente instructivos los estudios acerca de estos compositcres, porque iluminan el ambiente cultural de la época y la estética de escritores, poetas, e intelectuales de la vanguardia en Cuba. El autor concluye señalando las últimas tendencias de la posguerra y el estado de la música cubana en r945. La bibliografía atestigua las múltiples facetas de su cosmovisión y el sólido conocimiento del folklore y de las letras americanas, latentes asimismo en sus obras de imaginación.

En Los fugitivos, Carpentier se remonta otra vez al siglo XIX, contando una historia de solidaridad con trágico desenlace: dos seres en busca de libertad, Cimarrón y Perro. Es probable que pertenezca a la misma época que Viaje a la semilla puesto que en los dos cuentos aparecen, aunque sea de paso, personajes parecidos: el calesero Melchor y el calesero Gregorio; don Marcial, Marqués de Capellanías y don Marcial, señor de ingenio. A pesar del ambiente colonial en que transcurre la acción de ambas historias, Los fugitivos es un relato de índole muy distinta al de Viaje a la semilla. En el primero la trama disqurre con arreglo a la técnica tradicional. Un esclavo, huido de un ingenio, se une a un perro, que por seguir la pista de una perra en celo, ha abandonado el rastro de su jauría, cazadora de negros fugitivos. Hombre y animal, unidos por las mismas apetencias de comida, calor y hembra, cazan y roban juntos, y comparten la misma guarida, hasta que el negro, cada vez más imprudente en su busca de mujeres y aguardiente, es apresado por el mayoral de la hacienda. El perro desamparado olvida progresivamente su convivencia con el hombre y acaba subiendo al monte donde ingresa en una bandada de perros jíbaros. Un día, siguiendo el rastro de una de las piezas grandes que cazan en manada, los perros salvajes topan con el esclavo que ha conseguido romper las cadenas y escapar. El perro lo reconoce, pero sucumbe al instinto de destrucción adquirido en largos años de aleccionamiento por el mayoral y mata al negro.

El cuento se destaca por su sólida estructuración, la sorprendente identificación de hombre y animal a través del relato, y la cuidadosa 
descripción de la naturaleza tropical. La presencia de plantas y árboles como las pitahaya, bejuco-lombriz, culantrillo, y guayabera, ceiba, aromo, mamey, y de insectos y animales como zunzún, rana toro, majá, jutía y manatí, demuestran el hondo conocimiento que el autor tiene del campo cubano.

En El reino de este munido, Carpentier se aleja por primera vez de este ambiente, cuyos diversos semblantes en el tiempo exploró en obras anteriores. Mientras ;Ecue-Yamba- $\widehat{O}$ ! abatca la vida de la población negra en el campo y en la ciudad después de la Primera Guerra Mundial, los dos cuentos posteriores presentan distintas clases sociales de la época colonial: la existencia del hacendado Marqués de Capellanías en Viaje a la semilla y el destino del esclavo Cimarrón que huye del ingenio en Los fugitivos. En El reino de este mundo, revive sangrientos capítulos de la historia haitiana, donde como bien observa Salvador Bueno, "choca el mundo ilustrado del iluminismo francés dieciochesco, con el poderoso impulso espontáneo y natural del mundo mágico afroamericano". ${ }^{57} \mathrm{La}$ tendencia del realismo mágico que aparece en Viaje a la semilla, alcanza su plenitud en $\mathrm{El}$ reino de este mundo, en cuyo prólogo ataca Carpentier despiadadamente fantásticos códigos surrealistas, y define a continuación su teoría de lo real maravilloso: "... lo maravilloso comienza a serlo de manera inequívoca cuando surge de una inesperada" alteración de la realidad (el milagro), de una revelación privilegiada de la realidad, de una iluminación inhabitual o singularmente favorecedora de las inadvertidas riquezas de la realidad, de una ampliación de las escalas y categorías de la realidad, percibidas con particular intensidad en virtud de una exaltación del espíritu que lo conduce a un modo de "estado límite' ".58 Carpentier cree que el mundo americano revela lo real maravilloso con fuerza singular porque alli, "... todavía no se ha terminado de establecer... un recuento de cosmogonías" y concluye con que "... por la virginidad del paisaje, por la formación, por la ontología, por la presencia fáustica del indio y del negro, por la Revelación que constituyó su reciente descubrimiento, por los fecundos mestizajes que propició, América está muy lejos de haber agotado su caudal de mitologías". 59

El relato mismo narra con gran exactitud una serie de extraordinarios acontecimientos, que ocurrieron en el proceso histórico de la independencia de Haití, durante la segunda mitad del siglo Xvir, y principios del siglo xix. La acción se desarrolla en torno de tres acontecimientos ini-

57 S. Bueno, La letra como testigo, op. cit., p. 168.

58 El reino de este mundo, op. cit., pp. 10-11.

59 Ibid., pp. 15 y 16. 
ciales de la historia del país, en los que támbién participa el personaje principal Ti Noel. Conocemos al esclavo negro desde el comienzo, cuando visita la Ciudad del Cabo Francés en compañía del amo Lenormand de Mezy, dueño de una hacienda en la Llanura del Norte. Es la época en que largos años de descontento culminan en la insurrección de esclavos que, bajo órdenes del hechicero Mackandal, héroe precursor de la libertad de su pueblo, empiezan por envenenar el ganado y acaban por hacerlo con sus señores blancos. El primer capítulo de la independencia de Haití cierra con un milagro en la plaza pública el día de la ejecución del mandinga. La ciega fe de las masas autosugestionadas de negros, traídos al espectáculo para un escarmiento, les hace creer en la salvación de su jefe: "Mackandal sauvé". El segundo capítulo se inicia poco después de la Revolución Francesa y de la Declaración de los Derechos del Hombre. La noche del 15 de agosto de I79r los cabecillas revolucionarios Bouckman, Jean François, Biassou, Jeannot y un gran número de iniciados, se reúnen en el Bois Caiman. Bebiendo la sangre de un cerdo negro, firman un pacto mayor de guerra contra los blancos. Una semana después incendios y motines populares marcan el principio de la lucha por la libertad. Los propietarios ya no consiguen hacerse respetar por sus antiguos siervos, y la mayor parte de los terratenientes, entre ellos Lenormand de Mezy y su criado Ti Noel, se refugian en Santiago de Cuba. En 1793 se proclama la abolición de la esclavitud.

Las campañas del General Leclerc, que llega a la isla a reestablecer el orden, acompañado de su esposa Paulina Bonaparte, degeneran después de su muerte en los horrores del gobierno de Rochambeau. Es la funesta etapa final antes de la derrota francesa. El tercer capítulo narra la fase culminante de la independencia, el prodigioso reinado de Henri Cristophe. El "Primer Monarca Coronado del Nuevo Mundo", muda el yugo blanco de su pueblo por un despotismo negro igualmente sangriento y levanta monumentos a su orgullo en el Palacio de Sans Souci, y en la Ciudadela de La Ferrière. En el capítulo cuarto se narran casi en forma de epílogo los últimos episodios de muchos protagonistas que aparecieron en el curso del relato: el exilio de la reina y de las princesas en Roma, y la vida de Ti Noel entre las ruinas de la hacienda de su amo, ahora amueblada con despojos provenientes del saqueo de Sans Souci. El personaje principal de Ti Noel no muere; desaparece con un ciclón verde: metamorfoseado en buitre se hunde en "las espesuras del Bois Caiman".

El relato se atiene con asombrosa atención al detalle a la esencial realidad de las circunstancias históricas. Tanto que Salvador Buenc 
rechaza el término de "novela histórica" y prefiere el de "crónica legendaria" del pasado haitiano.60 Junto a los personajes ficticios, Lenormand de Mezy y Ti Noel, amo y esclavo, figuras que personifican los dos mundos que chocan en el relato, encontramos personajes históricos absolutamente fidedignos: el hechicero Mackandal, el caudillo jamaiquino Bouckman, el rey Henri Christophe, su esposa María Luisa, las princesas Ametista y Atenais, el confesor francés Cornejo Breille, el General Leclerc, Paulina Bonaparte, su masajista negro Solimán, el compositor cubano Esteban Salas. El aporte singular del autor "... -consiste en la disposición de los elementos y en el enfoque con que ellos son presentados al lector... Seleccionando los episodios, presentando a sus personajes - Mackandal, Bouckman, Henri Cristophe, Paulina Bonaparteen un momento culminante de sus increíbles aventuras, ordenando los objetos y el paisaje desde un ángulo que agudiza la incongruencia y el absurdo poético, la historia adquiere en manos de Carpentier un aire de locura, un frenesí de pesadillesco movimiento, una riqueza de asociaciones que tan pronto tocan a los sentidos como al intelecto". 61

En la novela que sigue a El reino de este mundo Carpentier presenta una visión mucho más amplia y universal del continente americano. El protagonista de Los pasos perdidos es un intelectual de ascendencia hispanoamericana, quien consigue deshacerse de la tiranía de su profesión y de la civilización mecanizada huyendo a la selva venezolana donde encuentra una existencia apegada a ritmos primordiales del mundo. El argumento tiene antecedentes literarios y posibles fuentes en obras tales como Heart of Darkness (rgo6), de Joseph Conrad, The Sea and the Jungle (r912), de Henry Major Tomlinson, The Lost World (I9I2); de Sir Arthur Conan Doyle, La vorágine (1924), de José Eustasio Rivera, y Lost Horizon (I933), de James Hilton. Marlow, el personaje principal de Heart of Darkness, remonta el gran río de una desconocida región africana, y tiene la impresión de viajar hacia el más remoto origen de la creación donde encuentra la encarnación del mal rodeada de una naturaleza salvaje. Tomlinson cuenta la historia de un personaje que deja las estrechas calles de Londres una mañana de invierno a fin de emprender un maravilloso viaje a la América del Sur. Y como apunta el propio autor en el título: "The Sea and the Jungle, being the narrative of the voyage of the tramp steamer 'Capella' from Swansea to Santa Maria de Belem do Grão Pará in the Brazils, and thence 2000 miles along the forets of the Amazon and Ma-

60 La letra como testigo, op. cit., p. 168.

61 Fernando Alegría, op. cit., p. 356. 
deira Rivers to the San Antonio Falls; afterwards returning to Barbados for orders, and going by way of Jamaica to Tampa in Florida, where she loaded for home. Done in the years I909 and I9Io". En The Lost IWorld, de Conan Doyle, uno de los autores predilectos de Carpentier, cuatro exploradores ingleses, Edward Malone, periodista de la Daily Gazette, el profesor Challenger y el profesor Summerlee, dos hombres de ciencia, junto con el intrépido cazador Lord John Roxton, navegan un tributario desconocido del Amazonas. Llegan a un alto cerro rocoso y suben a la meseta donde hallan fabulosos animales prehistóricos en el mundo perdido del planalto. En el caso de La vorágine Arturo Cova, el protagonista, huye de la sociedad acompañado de Alicia y los dos se hunden en la inmensa soledad de la selva amazónica hasta que el infierno verde devora a la pareja. Y en Lost Horizon, el protagonista, Conway, encuentra el secreto de la longevidad en Shangri-la, un remoto monasterio tibetano fuera de las leyes del tiempo normal, y vuelve a perderlo cuando regresa a la civilización. A Los pasos perdidos Carpentier aporta el tema de la relación del artista a su época, una nueva visión de América, que se contrapone a la cultura occidental en decadencia, un vasto caudal de erudición $y$, sobre todo, la preocupación perenne de la interpretación artística del tiempo: "En ese libro el argumento sólo tiene una función de elemento estructural, de factor de unidad. En Los pasos perdidos domina una idea: la de una evasión posible en el tiempo".62 Así y todo, los temas y las consideraciones filosóficas de la novela se agrupan alrededor de un hecho real del que nos informa el autor cuando nos cuenta el génesis de la obra:

...en el año I947, hallándome en Venezuela, tuve el deseo de remontarme a la selva virgen, o sea a la naturaleza del cuarto día de la Creación. Para ello salí de Caracas, crucé una parte importante del país, llegué a Ciudad Bolívar a orillas del Orinoco... poco a poco remontando el Orinoco, me fui dando cuenta de que hay un tiempo espacio americano, porque fuimos haciendo escala en pequeñas poblaciones de las orillas donde, a medida que íbamos avanzando durante esa navegación de veinte días... iban desapareciendo las civilizaciones y se iba entrando en una vida que se parecía. . a la Edad Media en Europa... Remontando el Orinoco digo, y entrando en la zona amazónica, me encuentro que América es uno de los pocos lugares del mundo donde el hombre del siglo xx, el hombre del año

62 Citado por Salvador Bueno en "Alejo Carpentier, novelista antillano y universal", La letra como testigo, Santa Clara, Cuba, 1957, p. 173. 
I964, puede convivir con el hombre que corresponde a la era diríamos del paleolítico o del neolítico en la historia humana. Se puede pasar por ciudades cuya vida era muy semejante a la Edad Media, y fui remontando poco a poco, hasta las regiones habitadas por los indios shirisanas y guatichanas que son posiblemente, la representación más elemental de la vida del hombre en el planeta.63

Como bien señala Fernando Alegría, El acoso es una síntesis de experimentos con esa noción del tiempo que el autor inicia en Viaje a la semilla y en Los pasos perdidos y prosigue en dos cuentos de Guerra del tiempo publicados en 1958, a saber, El Camino de Santiago y Semejante a la noche. El acoso es "una aplicación perfecta de las teorias de Carpentier a la técnica de la narración", que desarrolla en estas obras bajo enfoques distintos. El tiempo objetivo de la acción que transcurre en la novela, historia de un delator acorralado y fusilado como una alimaña en una sala de conciertos por una organización terrorista de La Habana, está cuidadosamente limitado a 46 minutos, tiempo aproximado de duración de la Tercera Sinfonía, la Eroica, de Beethoven. Los episodios descritos no son sino una selección de momentos cruciales en la vida de los protatgonistas principales, el taquillero y el acosado, natrados en forma de recuerdos, asociación libre de ideas, "flash-backs" y monólogos interiores.

Carpentier intencionadamente estructura $E l$ acoso como una sonata en tres movimientos. El primero, expositivo, comprende tres temas: el del taquillero, el del acosado y el de la ramera Estrella. El segundo consiste en trece variaciones en las que se desarrollan los temas expuestos, y el tercero, conclusión o coda de movimiento vivo, es una recapitulación de los temas principales. ${ }^{65}$ En la primera parte se inicia el relato en el vestíbulo de una sala de conciertos donde se ejecuta la sinfonía Eroica. Contemplamos la escena a través de impresiones, pensamientos y recuerdos de infancia de un taquillero estudiante de música. Sus reflexiones son interrumpidas por la llegada de un individuo que compra una butaca, arrojando un billete a la ventanilla y entra apresuradamente en la sala seguido por dos hombres. La segunda escena presenta el angustiado monólogo interior de un desconocido que escucha la sinfonía. El personaje balbucea oraciones y frases entrecortadas sin articulación lógica aparente,

53 Alejo Carpentier, "La cultura en Cuba y en el mundo", programa semanal de Radio Habana, Cuba, domingo 26 de febrero de 1965, conferencia grabada en cinta magnetofónica.

64 Fernando Alegría, op. cit., p. 370.

65 "Confesiones sencillas...", op. cit., p. 33. 
que dan la sobrecogedora impresión del miedo tremendo de alguien que huye de sus perseguidores. Ahora bien, no nos enteramos de que el individuo del monólogo no es el taquillero hasta la tercera escena. Aquí reaparece este personaje en casa de una prostituta después de abandonar la sala de conciertos. Cuando intenta ser aceptado con el billete de banco que el desconocido le ha dado, resulta ser éste falso y la mujer le echa de la casa. Así vuelve al teatro exasperado, bajo el enervante latido de su libido insatisfecho. En trece variaciones sobre los tres temas expuestos que se desarrollan en la segunda parte, aparecen ocasionalmente breves noticias, a manera de piezas de un mosaico que nos fuera dado montar, para llegar a la fatal secuencia final cuya culminación es la caza del hombre.

La historia que se revela paulatinamente es la de un joven bachiller del pueblo de Sancti Spíritus que viene a La Habana a estudiar arquitectura. Una vez aclimatado a su nuevo ambiente el muchacho participa en manifestaciones estudiantiles y acaba ingresando en el Partido Comunista del que luego se aleja, para unirse al "bando de los impacientes", un grupo de activistas comprometidos en la lucha sin cuartel contra el régimen dictatorial. El idealismo y la camaradería de los primeros días desemboca en actos cada vez más radicales. El joven abandona por completo su carrera y comete una serie de crímenes que intenta justificar por su actitud de oposición al gobierno. Un día la organización le exige que participe en el fusilamiento de un amigo. El delator ha traicionado a unos compañeros que planeaban un atentado en un cementerio contra las autoridades y los parientes asistentes al sepelio de un asesinado por razones políticas. A los "tiempos del tribunal" siguen los "tiempos del botín". El grupo de agitadores ha degenerado disgregándose en bandas terroristas dedicadas al pillaje. Aprovechándose del miedo que infunden sus miembros trafican con la violencia, cometen muertes a sueldo y venden sus servicios a poderosos hombres públicos. Paso a paso se encuentra sumergido en la "burocracia del horror". A la ejecución colectiva sigue el asesinato a sangre fría. Tiene que disparar a la nuca de un individuo porque su muerte favorece a un alto personaje. Llega el día en que un político le paga la preparación de una máquina infernal, disimulada en el grueso volumen de una antología de oradores, destinada a estallar en manos de un enemigo. Al día siguiente la policía sorprende al estudiante y le mete en la cárcel. Bajo la amenaza de tortura y emasculación, delata a la pandilla y revela la residencia de sus camaradas. Los terroristas que sobreviven a la matanza orga- 
nizada por la policía, empiezan el acoso del traidor que ha sido puesto en libertad. El acosado escapa de ser acribillado' a balazos y se refugia en el mirador del piso de su vieja nodriza negra. Enferma ella, pasa cuatro días de hambre sin atreverse a asomarse a la calle. En los días del encierro, durante la enfermedad de la vieja, tiene alucinaciones religiosas y escucha infatigable la Eroica que toca sin cesar un estudiante de música que vive en un alto edificio moderno, contiguo. La muerte de su protectora le obliga a salir de su escondite y huir: de nuevo. Buscando las sombras de edificios y columnas se encamina hacia la casa de Estrella, la ccima, a quien cuenta los pormenores de lo ocurrido. Le pide que lleve un recado a un alto funcionario del gobierno. Pero también se ve forzado a abandonar la casa de la buscona cuando ésta vuelve con un conductor de taxi con quien tiene que acostarse para pagar el alquiler del coche. El billete que le había dado el estudiante era falso. Cansado, medio muerto de hambre y falto de sueño se acoge a una iglesia. Ttata de confesarse con el párroco que le arroja del templo porque cree que el acosado es un devoto de la santería. El fugitivo intenta regres̀ar nuevamente a casa de su nodriza. En el camino se encuentra con sus perseguidores. Con sus últimas fuerzas sale corriendo desesperadamente y escapa metiéndose en la sala de conciertos donde se ejecuta la Eroica. Es el desconocido que al principio del relato arroja a la taquilla el billete que ha de resultar falso.

La tercera parte concluye muy rápidamente en dos escenas finales en que reaparecen los tres temas de la primera parte: el monólogo interior del acosado, las fantasías del taquillero y Estrella. La muerte del acosado es casi anticlimática: los verdugos disparan dos veces a la alfombra donde yace la víctima extenuada. Si bien los diversos sucesos ocurren en un lapso de tiempo de semanas, meses y años en la vida de los personajes, cuyas existencias se cruzan y entrecruzan a través del relato, en última instancia, la peripecia en sí, dura el tiempo indicado para la ejecución de la sinfonía Eroica", ... composta per festeggiare il souvvenire di un grand'Uomo...", cuyo irónico principio y fin sirven de marco para la acción. "Los episodios, las palabras, los gestos, van buscando el lugar que les corresponde en el 'puzzle' hasta que, al integrarse en la imagen final, se ha producido el desenlace y la historia entera se ilumina en toda su genial complejidad". 66

En Guerra del tiempo, Carpentier reúne varios relatos: Viaje a la semilla, El acoso y dos cuentos inéditos El Camino de Santiago y Semejante

66 F. Alegría, op. cit., p. 370. 
a la noche. El título viene del primer acto de una comedia de Lope de Vega, El servir a señor discreto: "QQué capitán es éste, qué soldado/de la guerra del tiempo más deshecho/que de la mar?..."'67 Y como bien apuntan los editores, "Ese Capitán, ese Soldado, es el Hombre, siempre semejante a sí mismo, inmensamente fiel a sus 'constantes' aunque el 'Tiempo transcurra, llevándose trajes, disfraces, modas de un día, fiebres transitorias". En El Camino de Santiago y Semejante a la noche el autor rompe los confines temporales del hombre por medio de un acto creador, la adopción del concepto de tiempo mítico imaginario.

La época en que transcurren los acontecimientos de El Camino de Santiago corresponde a finales del siglo xV. Un soldado español, tambor de tropa del tercio de Flandes, cae enfermo durante una epidemia que azota los Países Bajos. A fin de librarse del mal hace la promesa de peregrinar a Santiago de Compostela siguiendo la vía láctea que de noche se encienda en el cielo. Se pone en camino, pero a medida que recobra la salud, afloja más y más en su empeño. En la plaza pública de Burgos se detiene a escuchar portentosas novedades americanas: noticias de una arpía americana, la tierra de Jauja, y las conquistas de Pizarro en el Perú. El diablo en figura de un ciego entona el romance de partida "Ãnimo, pues, caballeros,/Ãnimo pobres hidalgos,/" y los embustes de un viejo indiano acompañado de un negro y de un papagayo, le desvían de cumplir su voto. Alentado por los sueños de fortuna el peregrino ahora marcha hacia Sevilla, de donde salen flotas para el Nuevo Mundo. En el libro de la Casa de Contratación Juan el Romero se inscribe como Juan de Amberes, que pide permiso para embarcar rumbo a la Nueva España. Pero en su estancia en San Cristóbal de La Habana paga él aprendizaje del desengaño. Entre pasar hambre, comadreos y chismes, lleva "la vida más perra que arrastrarse pueda en el reino de este mundo". Cuando apuñalea a un genovés por una pendencia de mujeres, se ve forzado a huir lejos, al otro extremo de la isla. Alli se junta con otros fugitivos, un calvinista, un judío marrano y un negro cimarrón. A pesar de la añoranza de Europa que siente en el exilio. América poco a poca va cambiando su modo de ser. Se acostumbra a los nuevos sabores del jitomate, casabe y carne asada con polvo de chile, se hace más tolerante con los herejes y se aficiona a las hembras negras. Por ello reconoce que al regresar al viejo mun'do, ya no lo encuentra apetecible como antes. En todas partes arden hogueras de la Inquisición que persigue implacablemente a los heterodoxos. Juan de Amberes es ahora Juan el Indiano que ven-

67 Guerra del tiempo, op. cit., p. 10. 
dẹ buhonerías del Potosí por los caminos de España, acompañado de un negro y un papagayo. El relato cierra su estructura circular el día que Juan el Indiano encuentra a Juan el Romero en la plaza de Burgos. Hay un desdoblamiento del protagonista central en dos personajes distintos, y el uno va a revivir ahora las aventuras y el viaje que el otro acaba de recorrer.

En la escena inicial de Semejante a la noche un joven contempla el embarque de provisiones en naves griegas poco antes de salir con la flota a la guerra de Troya. La segunda escena transcurre en tiempos de la conquista de América; un soldado observa a los marineros que están alistando "La Gallarda". el día antes de zarpar a las Indias. Y en la tercera, un muchacho riñe con su enamorada en vísperas de su partida para América, poco después corre a holgarse una vez más en brazos de una bailarina. Otro cuadro de embarcación, esta vez en Francia a fines del siglo xvir. En la cuarta escena un joven medio embriagado y cansado después de haber pasado la noche en vela con una mujer, encuentra a su prometida con quien riñó durante la tarde, acostada en su cama. Extenuado por sus recientes excesos el mozo no consigue enardecerse y la novia le deja con desprecio. Pero, de repente, advertimos de que este episodio, que parecía ser una continuación de la escena anterior, ha tenido lugar siglos antes, durante la partida de la flota griega a Troya. El hilo de la acción ha hilvanado en distintas épocas sobre el fugitivo correr del tiempo que va y viene en la historia como el movedizo telón de fondo del escenario de un teatro.

En $E l$ Camino de Santiago y Semejante a la noche la angustia del hombre frente al implacable transcurso del tiempo se resuelve, pues, mediante la creación de un tiempo mítico, lo que equivale a la negación absoluta del tiempo histórico, comentado por la crítica: "One way certain intellectuals have found of coping with their fear is to deny historical time and induce in themselves through aesthetic and ideological means a sensation of mythic time - the eternal past of ritual. The advantage of mythic time is that it is without definite articulation, confounding past, present, and future in an undifferentiated unity, as against historical time which is unrepeatable and of an ineluctable progression. The historical event of myth that, recurring again and again, is endlessly present". ${ }^{68}$ Y Fernando Alegría añade "Carpentier experimenta en estas obras con una idea que le parece haberle obsesionado largamente: la de romper los márgenes artificialmente sólidos del tiempo y de integrar el

ds Philip Rahv, The Myth and the Powerbouse, N, Y., Farrar, Strauss and Giroux, 1965, p. 14, 
pasado, el presente y el porvenir en una duración, a la vez, estable y voluble, cuyo eje puede ser una persona, un acontecimiento o una vida integra. Que esta idea no es del todo original, no hace falta decir; antecedentes de Carpentier son a este respecto: la comedia romántica de John Balderston, Berkeley Square y la novela lírica de Virginia Wolf, Orlando".69 No obstante la dolorosa y obsesiva conciencia del correr del tiempo que el escritor manifiesta en Guerra del tiempo y también en Los pasos perdidos ofrece distintas soluciones al hombre según su circunstancia. El transcurso del tiempo que el autor imagina como una contienda interminable tiene victorias, derrotas y treguas. Viaje a la semilla, El acoso y Los pasos perdidos muestran que el hombre sólo puede regresar al pasado y a la pureza perdida de la infancia a través del recuerdo. Y en Los pasos perdidos también vemos, como victoria sobre el tiempo, la intemporalidad o perennidad de la obra de arte.

El siglo de las luces es la culminación de la tendencia hacia una visión progresivamente más amplia y universal de la realidad àmericana patente en las novelas de Carpentier. Es el fruto de un lógico desarrollo que le lleva desde la interpretación relativamente local de elementos africanos en Cuba, pasando por la recreación de dramáticos momentos del pasado de Haití en El reino de este mundo, y el descubrimiento de prototipos de ciudades, pueblos y remotos rincones del continente en Los pasos perdidos, a la composición de toda una "Sinfonía del Caribe", donde los sonoros temas entonados en la Revolución Francesa repercuten en el ancho y tornasolado mundo de las Antillas. A esas razones podemos agregar que la obra también señala la dirección en que, según el autor, debe marchar su narrativa y la novela hispanoamericana: "Le roman sud-américain doit montrer la transformation de groupes en mouvement. en action. C'est pourquoi mes romans ont peu de personnages. Mon prochain roman $E l$ año 59, inspiré par la Révolution cubaine, será d'ailleurs un roman sans personnages. Les cas individuels ne sont plus possibles. Le roman est devenu un moyen d'exploration de certaines collectivités, et un lien entre le particulier et l'universel". ${ }^{70}$ La colectividad que explora en $E l$ siglo de las luces, el impacto producido en sus dominios por las ideas y acontecimientos de la Revolución Francesa, es "todo el ámbito del Caribe" en un determinado momento histórico, el fin de una época simbolizado por el cuadro de Monsú Desiderio "Explosión en una catedral", en la segunda mitad del siglo xvirr. "En los siete capítulos el escenario fasa de La Habana, a Santo Domingo, Francia, la Gua-

69. Op, cit., p. 369 .

70 Claude Fell, op. cit., p. 105. 
dalupe, Cayena, Paramaribo, otra vez La Habana, Cayena, y España. La acción comienza en un solar colonial habaneto donde tres jóvenes cubanos, los hermanos Carlos y Sofía, junto con su primo Esteban, llevan una vida desordenada de reclusos después de la muerte del padre. El albacea se encarga de administrar los negocios y les satisface todos los antojos. Un día llega un negociante de Port-au-Prince, Víctor Hugues, quien transforma este modo de vivir. Trae un médico que restablece la salud amenazada de Esteban, pone orden en el almacén e inicia a los tres en la masonería y en las ideas del iluminismo francés diciochesco. Cuando las autoridades españolas desatan una persecución contra los masones Víctor Hugues huye en un buque norteamericano acompañado de Sofía y, Esteban. Al llegar a Santiago de Cuba advierten que la rebelión de esclavos ha estallado en Port-au-Prince. Mientras Sofía se queda en Santiago, Esteban y Víctor prosiguen el viaje a la colonia francesa donde encuentra la ciudad en llamas. El joven cubano sigue a Víctor Hugues a Francia, participa en la revolución y asiste al meteórico ascenso del francés hasta el cargo de agente del Directorio. En los episodios posteriores alternan vivas escenas bélicas de las tropas francesas en ultramar mandadas por Hugues contra los ingleses en la Guadalupe, con actividades corsarias antillanas y líricas descripciones de la naturaleza tropical. También aparecen cuadros alucinantes de los pudrideros de Cayena pintados con amargas tintas dignas de los trece escalofriantes Caprichos de Goya cuyos títulos encabezan jornadas y capítulos de la narración: Siempre sucede, ¿Qué alboroto es éste?, Sanos y enfermos, Fuerte cosa es, Estragos de la guerra, Extraña devoción, Se aprovechan, Las camas de la muerte, Fiero monstruo, Con razón y sin ella, No hay que dar voces, Amarga presencia, Así sucedió. Si recordamos que Jorge Manach y los jóvenes de la vanguardia cubana conmemoran el centenario de la muerte del pintor en las páginas de la Revista de Avance, abril, mayo y agosto de I928, no nos extraña la función que Carpentier asigna a estos aguafuertes: "Elles conduisent le lecteur vers un dénouement que je croyais goyesque. Toute la fin est une vision de Goya. D'ailleurs, quan j'ai un chapitre difficile à faire, je pense toujours à un peintre: Vermeer, Bosch, Goya, Picasso. Le livre est dominé par la couleur rouge, il n'y a pas un chapitre où l'image du sang est absente (couraux, sang, guillotine, etc,...). Le rouge est une constante et ne disparait qu'à la fin quand on ferme les rideaux de la maison de Madrid, alors que Sofía et Esteban ont disparu dans le soulèvement du 2 mai contre les troupes napoléoniennes". ${ }^{2}$ El

71 Claude Fell, op. cit., pp. 106-107. 
autor advierte también el valor simbólico con que cada uno de sus personajes principales desborda el estricto papel que desempeña en la novela. Así el protagonista central Víctor Hugues es el político puro, para quien no existen ideas filosóficas, y para el que todos los medios que le llevan a un determinado fin son buenos; Esteban el intelectual contemplativo, sensible a los males de la sociedad y dispuesto a cambiarlos conforme a esquemas teoréticos; Sofía, o la sabiduría, la mujer capaz de entender el significado y prever las consecuencias de ideas en el campo de la política. ${ }^{72} \mathrm{Y}$ como destaca Claude Fell, aunque las situaciones y relaciones formales entre estos personajes se correspondan bien con las de la novela clásica, hermano y hermana, amante y querida, la perspectiva es nueva: ". ...ce qui intéresse le romancier, c'est en réalité l'analyse des rapports qu'entretiennent la nature, l'histoire et l'homme. A cet égard, l'attitude de Carpentier est claire; pour lui, l'événement dépasse l'homme, le déconcerte, le balaie parfois, mais à travers les idées l'homme retrouve une prise sur le réel. C'est le sens de la phrase placée en exergue au Siècle des Lumières: 'Las palabras no caen en el vacío' (Zohar)... L'événement triomphe de l'homme mais l'idée finit toujours par triompher de l'événement".73

Para concluir el esbozo de las obras principales cabe examinar de paso el último libro de ensayos, Tientos y diferencias. En Problemática de la actual novela latinoamericana Carpentier presenta su teoría de la literatura contemporánea y su definición de lo que debe ser la novela en Hispanoamérica. Según él ha de escribirse dentro del preceptivismo de Jean Paul Sartre. Contextos raciales, económicos, políticos, burgueses, de distancia y proporción, desajuste cronológico, culturales, culinarios, iluminación, ideológicos, son factores todos ellos que revelan mejor la gran mezcla de culturas que representa el continente americano que rebuscados cuadros tipicistas y costumbristas. A la luz de esta interpretación justifica su estilo y la dimensión épica de sus novelas. Del folklorismo musical es una investigación de los problemas del nacionalismo en una búsqueda y definición de lo que imprime su acento peculiar a la producción musical de un país. La ciudad de las columnas es La Habana. El ensayo, escrito como texto para un album de Paolo Gasparini, cuyas doce mejores fotografías se incluyen en Tientos y diferencias, contiene comentarios sobre historia, estilo y desarrollo de la arquitectura cubana. Literatura y conciencia politica en América Latina, discurso pronunciado en el Primer Congreso de

72 Claude Fell, op. cit., p. 103.

73 Ibid., p. 103. 
Escritores y "Artistas Cubanos en 196r, e impreso más tarde, es una apelación a la unidad de los hombres de letras de Hispanoamérica. Después de atacar la actitud apolítica de ciertos intelectuales frente a las condiciones que les circundan y el estado de miseria en que vive el pueblo en muchos países del continente, destaca la necesidad de comunicarse, comprometerse y definirse dentro de las estructuras políticas. Así cree que los escritores llegarán a un sentido nuevo de lo que significa ser americano y a una "conciencia ecuménica, universal, de los problemas sociales latinoamericanos". Bajo el título de Ser y estar el novelista recoge tres opúsculos titulados: Robert Desnos, el bombre poeta; Cuevas y Kafka; y Calder, calderero prodigioso. El primero es un breve esbozo biográfico de Robert Desnos, cuyos ensayos inéditos Lautréamont y El porvenir de América Latina traducidos por Carpentier, aparecen en el apéndice. Cuevas y Kafka es un comentario acerca de veinte dibujos del pintor mexicano José Luis Cuevas para El mundo de Kafka y Cuevas. Y Calder, caldevero prodigioso es una introducción escrita con motivo de la exposición caraqueña de 1955 de los móviles del artista. En De lo real maravillosamente americano elabora la teoría de la vigencia de lo real maravilloso en América ya explicada en el prólogo de la primera edición de $E l$ reino de este mundo.

El análisis de la vida, influencias ambientales, trayectoria artística y producción literaria de Carpentier, en que hemos tratado de fijar críticamente validez y significación de autor y obra en su época, nos permite concluir con las siguientes consideraciones. La formación intelectual de Carpentier es el producto aventajado de una educación cosmopolita, síntesis de lo americano y europeo. Desde los primeros momentos destaca su identificación sin reservas con las aspiraciones de sus coterráneos; junto con Jorge Mañach; Juan Marinello, Francisco Ichaso y Martí Casanovas es uno de los iniciadores del movimiento vanguardista en Cuba, donde encuentra amigos y colaboradores. Participa en el surrealismo en París y llega a conocer las figuras principales de esta corriente innovadora. Actúa como periodista, director de programas de radiodifusión, musicólogo y escritor en Cuba, Francia y Venezuela, actividades en que adquiere la honda cultura que se refleja en su obra literaria. Hemos intentado seguir a la vez un desarrollo que va desde sus primeros temas afrocubanos, al realismo mágico. Por medio de innovaciones técnicas y tentativas varias de resolver serios problemas que plantea el tema tiempo; llega a una visión progresivamente más amplia del rico y abigarrado universo de Hispanoamérica, La producción novelístiça de Alejo Car- 
pentier brota, por tanto, como fruto de la interpretación de la realidad americana, en el determinado momento de la generación vanguardista, en la precisa circunstancia que el autor describe como "la del escritor. . nacido, amamantado, criado, educado en el ámbito propio, ...lúcido únicamente a condición de que desentrañe los móviles de la praxis" de la América Latina.

Klaus Müller-Bergh

Yale University 
